\title{
Pengaruh Penerapan Model Pembelajaran Numbered Heads Think Talk Write Together Terhadap Kemampuan Berpikir Kreatif Pada Mata Pelajaran Ekonomi Kelas XI IPS SMA Negeri 1 Patimpengkabupaten Bone
}

\author{
Haeril ${ }^{1}$, Muhammad Yany ${ }^{2 *}$ \\ Universitas Muhammadiyah Bone \\ Co - Author : $\underline{\text { muhammadyany1401@ gmail.com }{ }^{2 *} \text {, haerilkacong @ gmail.com }{ }^{1}}$
}

\begin{abstract}
Abstrak. Penerapan model pembelajaran merupakan salah satu faktor utama yang dapat mengembangkan keaftifan siswa dalam proses pembelajaran.Dengan model pembelajaran yang efektif akan berdampak pada hasil belajar siswa.penelitian ini bertujuan untuk mengetahui pengaruh penerapan model pembelajaran umbered heads think talk write together terhadap kemampuan berfikir kreatif pada mata pelajaran ekonomi kelas XI IPS SMA Negeri 1 patimpeng kabupaten Bone serta gambaran kemampuan berfikir kreatif siswa setelah penerapan model pembelajaran tersebut. Penelitian ini menggunakan desain None quivalent Control Group Design. Populasi diambil seluruh kelas XI IPS yang berjumlah dua kelas dan teknik pengambilan sampel yang digunakan adalah sampling jenuh. Pengujian IPK diperoleh nilai sebesar $(72,56)$ pada kelas eksperimen. Hal ini berarti kelas eksperimen setelah diberi perlakuan model pembelajaran Numbered Heads Think Talk Write Together mengalami perkembangan dari nilai IPK dengan kriteria rendah $(32,08)$ pada saat pretest kemudian berada pada nilai IPK kriteria sedang $(72,56)$ pada saat posttest, sehingga dapat disimpulkan bahwa model pembelajaran Numbered Heads Think Talk Write Together cocok digunakan pada pembelajaran berkelompok karena melewati standar nilai KKM sebesar 70,00 yang ditetapkan sekolah pada mata pelajaran ekonomi.Melalui pembelajaran Numbered Heads Think Talk Write Together dengan jumlah siswa kelas eksperimen sebanyak 25, siswa yang mencapai standar nilai KKM sebanyak 17 atau 68\%.
\end{abstract}

\section{PENDAHULUAN}

Kegiatan belajar mengajar di sekolah seharusnya mendorong siswa untuk mengembangkan kemampuan berpikir. Oleh karena itu, program pendidikan yang dikembangkan perlu menekankan pada pengembangan kemampuan berpikir siswa, yaitu berpikir logis, analitis, sistematis, kritis, dan kreatif (Prasetiyo \& Mubarokah, 2014:10). Salah satu kemampuan berpikir yang sering diabaikan dalam pendidikan formal adalah kemampuan berpikir kreatif (Sari, Sumiati, \& Siahaan; 2013:61).

Pendidikan formal selama ini hanya menekankan perkembangan yang terbatas pada ranah kognitif saja, sedangkan ranah afektif (sikap dan perasaan) kurang mendapat perhatian. Terbukti pada pembelajaran di sekolah, kegiatanyang menuntut pemikiran divergen atau berpikir kreatif masih terbatas sehingga siswa tidak terangsang untuk berpikir, bersikap, dan berperilaku kreatif. Oleh karena itu, dalam proses pembelajarandiperlukan cara yang mendorong siswaterlibat secara aktif meningkatkan kemampuan berpikir kreatifnyasehingga dapat mempermudah memahami pembelajaran. Di samping itu,mampu mendorong pembelajaran yang berpusat pada siswa, sedangkan guru bertindak sebagai fasilitator (Supardi, 2012: 249).

Berdasarkan hasil observasi pendahuluan pada saat melaksanakan Praktik Pengalaman Lapangan (PPL) di SMA Negeri 1 Patimpeng, guru mata pelajaran ekonomi belum efektif menggunakan model pembelajaran, kegiatan belajar mengajar masih berpusat pada guru (teacher centered) yang ditandai dengan pembelajaran menggunakan metode ceramah sehinggasiswa cenderung pasif, pembelajaran lebih menekankan memorisasi dan mencatat materi yang dipelajari tanpa memberikan kesempatan yang lebih luas kepada siswa untuk mengonstruksi sendiri pengetahuannya terhadap pembelajaran.Selain itu, guru belum optimal memanfaatkan fasilitas multimedia pembelajaran yang ada sebagai wadah untuk 
mengembangkan kemampuan berpikir kreatif siswa, guru hanya menggunakan buku paket sebagai media pembelajaran. Pembelajaran yang bersifat teacher centeredmengekang kreativitas siswa dan tidak menimbulkan suasana belajar interaktifsehingga berdampak pada hasil belajar siswa yang tidak maksimal.

Beberapa model pembelajaran kooperatif sudah mulai dikembangkan. Akan tetapi, peneliti memilih dua model pembelajaran yaitu model pembelajaran Numbered Heads Together (NHT) dan model pembelajaran Think Talk Write (TTW), kemudian dielaborasikan menjadi model pembelajaran terbaru menjadi model pembelajaran Numbered Heads Think Talk Write Together.

Model pembelajaran Numbered Heads Think Talk Write Togethermerupakan model pembelajaran kooperatif dengan pengelompokkan siswa dalam tim-tim pembelajaran antara lima sampai enam anggota tiap kelompok secara heterogen. Kegiatan pembelajaran menekankan siswa lebih berpikir daripada menghafal, memahami pembelajaran dengan baik melalui diskusi, mengembangkan kemampuan berpikir kreatif dalam menjawab permasalahan atau soal tes, mendorong siswa bersikap demokratis dalam efektivitas belajar dan dapat meningkatkan hasil belajar siswa.

Berdasarkan latar belakang di atas, maka perlu dilakukan penelitian untuk memecahkan permasalahan terkait rendahnya kemampuan berpikir kreatif siswa.Oleh karena itu, peneliti berinisiatif dan tertantang melakukan penelitian dengan mengimplementasikan model pembelajaran Numbered Heads Think Talk Write Together berbantuan media audio visual untuk memecahkan permasalahan terkait rendahnya kemampuan berpikir kreatif pada mata pelajaran ekonomi kelas XI IPS SMA Negeri 1 Patimpeng Kabupaten Bone.

\section{KAJIAN PUSTAKA \\ Pembelajaran}

Pembelajaran adalah suatu situasi yang tercipta dari interaksi yang berlangsung antara berbagai komponen pembelajaran, yaitu guru, siswa, kurikulum, metode, sarana, dan media serta komponen lainnya yang diperlukan. Tujuan yang diharapkan dari suatu pembelajaran tidak lain berkisar pada analisis tentang bagaimana cara menghilangkan kesenjangan antara perilaku yang ada sekarang dengan perilaku yang diharapkan di masa yang akan datang setelah melaksanakan kegiatan belajar mengajar.

Pembelajaran merupakan suatu proses interaksi yang terjadi antara guru dan siswa, agar siswa mendapatkan pengalaman belajar dari kegiatan pembelajaran. Dalam proses pembelajaran guru tidak hanya menyampaikan materi tanpa mengetahui siswa paham atau tidak. Akan tetapi, dapat membuat siswa memahami pelajaran agar dapat menerapkan dalam kehidupan sehari-hari.Pembelajaran kooperatif (cooperative learning) dapat diartikan belajar bersama-sama, siswa saling membantu antara satu dengan yang lain dalam mencapai tujuan atau tugas yang telah ditentukan. Dengan demikian, dapat dipahami bahwa cooperative learning menyangkut teknik pengelompokan yang di dalamnya siswa bekerja terarah pada tujuan belajar bersama dalam kelompok kecil yang terdiri dari empat sampai enam siswa (Isjoni, 2013:6).

\section{Model Pembelajaran Numbered Heads Think Talk Write Together}

Model Pembelajaran Numbered Heads Think Talk Write Together merupakan model pembelajaran hasil elaborasi atau modifikasi dari model pembelajaran Numbered Heads Together (NHT)dan Think Talk Write (TTW).

Model pembelajaran Numbered Heads Together(NHT) merupakan jenis pembelajaran kooperatif yang pertama kali dikembangkan oleh Spenser Kagen (1993) untuk melibatkan lebih banyak siswa dalam menelaah materi yang tercakup dalam suatu pelajaran dan mengecek permasalahan siswa terhadap isi pelajaran (Febriany, 2013:3).Model pembelajaran kooperatif tipe NHT dilandasi oleh teori belajar konstruktivis (Lie dalam Herawati, Wahyuni, \& Prihatin; 2014:74). Model pembelajaran Numbered Heads Together(NHT) mengelompokkan siswa dalam tim-tim pembelajaran dengan tiga sampai lima 
anggota tiap kelompok yang berbeda kemampuan, jenis kelamin, budaya, dan setiap anggota kelompok diberi nomor (Ellan, Hobri, \& Nurcholif;2013:2)

Model pembelajaran kooperatif tipe Think Talk Write (TTW) diperkenalkan oleh Huinker dan Laughl yang pada dasarnya dibangun melalui berpikir, berbicara, dan menulis(Suningsih, Kusmayadi, \& Riyadi; 2014:414). Model pembelajaran TTW berlandaskan teori belajar konstruktivisme, sebagaimana diungkapkan Lestasi (2011:116117) bahwa pembelajaran yang bernaung dalam teori kontruktivis adalah kooperatif. Pembelajaran kooperatif muncul dari konsep bahwa siswa akan lebih mudah menemukan dan memahami konsep yang paling sulit jika siswa berdiskusi dengan teman kelompoknya.

\section{METODE PENELITIAN}

\section{Jenis Penelitian}

Penelitian ini merupakan penelitian kuantitatif menggunakan metode penelitian quasi experimental design yang merupakan pengembangan dari true experimental design yang sulit dilaksanakan. Desain ini mempunyai kelompok kontrol tetapi tidak dapat berfungsi sepenuhnya untuk mengontrol variabel-variabel luar yang memengaruhi pelaksanaan eksperimen. Quasi experimental design digunakan karena pada kenyataannya sulit mendapatkan kelompok kontrol yang digunakan untuk penelitian (Sugiyono, 2014:117).

\section{.Lokasi dan Waktu Penelitian}

Penelitian ini dilaksanakan di SMA Negeri 1 Patimpeng Kabupaten Bone pada kelas XI IPS semester ganjil tahun ajaran 2019/2020.

\section{Variabel Penelitian}

Variabel merupakan objek penelitian yang menjadi titik perhatian utama dalam suatu penelitian (Ayuningtyas, 2011:35).Pada penelitian ini, peneliti menggunakan dua jenis variabel, yaitu:

Variabel independen atau variabel bebas (X) merupakan variabel yang memengaruhi atau yang menjadi sebab terjadinya perubahan atau timbulnya variabel terikat (Sugiyono, 2014:61). Variabel bebas pada penelitian ini adalah model pembelajaran Numbered Heads Think Talk Write Together yang memengaruhi variabel terikat (Kemampuan berpikir kreatif). Variabel dependen atau variabel terikat (Y) merupakan variabel yang dipengaruhi atau yang menjadi akibat karena adanya variabel bebas (Sugiyono, 2014:61). Variabel terikat dalam penelitian ini adalah kemampuan berpikir kreatif yang dipengaruhi oleh variabel bebas (Model pembelajaran Numbered Heads Think Talk Write Together).

\section{Definisi Operasional Variabel Penelitian}

Model Pembelajaran Numbered Heads Think

Talk Write Together adalah model pembelajaran kooperatif dengan pengelompokkan siswa dalam tim-tim pembelajaran antara lima sampai enam anggota tiap kelompok secara heterogen.

Kemampuan berpikir kreatif adalah upaya membuka pikiran untuk menemukan atau menciptakan berbagai gagasan atau pemikiranpemikiran baru dalam usaha memecahkan permasalahan yang sedang dihadapi.

\section{Desain Penelitian}

Penelitian ini menggunakan desain Nonequivalent Control Group Design. Populasi diambil seluruh kelas XI IPS yang berjumlah dua kelas dan teknik pengambilan sampel yang digunakan adalah sampling jenuh. Sampling jenuh merupakan teknik penentuan sampel apabila semua anggota populasi digunakan sebagai sampel (Sugiyono, 2014:124).

Adapun desain penelitian yang digunakan adalah sebagai berikut:

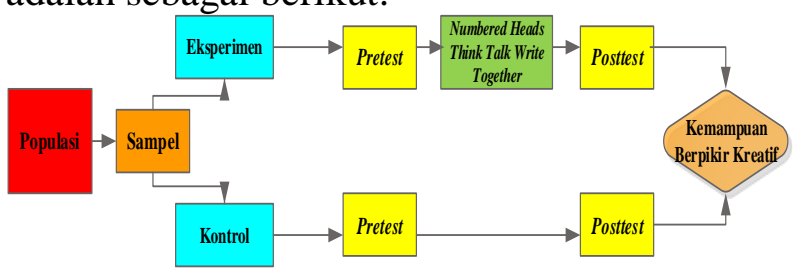

Gambar 3.1 Desain Penelitian Nonequivalent Control Group Design

\section{Instrumen Penelitian}

Instrumen adalah alat yang digunakan untuk memeroleh atau mengumpulkan data 
rangka memecahkan masalah (Muamar \& Amelia, 2013:36). Instrumen penelitian yang digunakan adalah observasi, wawancara, tes, dan dokumentasi.

\section{Observasi}

Observasi dilakukan oleh peneliti dengan cara pengamatan secara langsung selama kegiatan belajar mengajar mata pelajaran ekonomi pada siswa kelas XI IPS SMA Negeri 1 Patimpeng Kabupaten Bone.

\section{Wawancara}

Wawancara yang digunakan adalah wawancara tidak terstruktur dengan informan adalah siswa dan guru mata pelajaran ekonomi kelas XI IPS SMA Negeri 1 PatimpengKabupaten Bone, pedoman wawancara yang digunakan berupa garis-garis besar permasalahan terkait penggunaan model pembelajaran, pemanfaatan media pembelajaran, serta sikap dan karakteristik siswa terhadap proses pembelajaran mata pelajaran ekonomi.

Tes

Tes hasil belajar yang diberikankepada siswa berbentuk tes esai sebanyak 10 soal dikerjakan secara individu.Penyusunan soal tes kemampuan berpikir kreatif bertujuan untuk mengukur kemampuan berpikir kreatif siswa sebelum dan setelah proses pembelajaran menggunakan model pembelajaran Numbered Heads Think Talk Write Together.

\section{Dokumentasi}

Dokumentasi dilakukan bertujuan untuk mengungkapkan fakta atau sebuah bukti pada saat pelaksanaan penelitian, yaitu dokumentasi pada saat melakukan uji validitas dan reliabilitas soal di XI IPS SMA Negeri 1 Libureng Kabupaten Bone dan pada saat peneliti melakukan penelitian di kelas XI IPS SMA Negeri 1 PatimpengKabupaten Bone dengan menerapakan model pembelajaran Numbered Heads Think Talk Write Together untuk meningkatkan kemampuan berpikir kreatif yang diharapkan dapat berdampak pada hasil belajar siswa yang maksimal.

\section{Prosedur Pengumpulan Data}

Prosedur pengumpulan data pada penelitian ini dimulai dengan memberikan pretestkepada siswa pada kelas kontrol dan kelas eksperimen menggunakan soal yang sama sebelum melakukan pembelajaran di kelas. Selanjutnya, siswa pada kelas eksperimen mendapatkan perlakuan dengan menerapkan model pembelajaran Numbered Heads Think Talk Write Together yang diintegrasikan dengan pemanfaatan multimedia video pembelajaran pada materi ajar ketenagakerjaan, sedangkan pada kelas kontrol tidak diberi perlakuan atau tidak diterapkan model pembelajaran Numbered Heads Think Talk Write Together dengan pengintegrasian media pembelajaran video pada pembelajaran materi ketenagakerjaan, kemudian di akhir pembelajaran kedua kelas diberikan posttest untuk mengetahui pemahaman terhadap materi ajar. siswa.

\section{Teknik Analisis Data}

Teknik analisis data dalam penelitian ini dilakukan dengan perhitungan statistik dan melakukan perbandingan terhadap dua kelas yaitu kelas kontrol dan kelas eksperimen untuk mengetahui hasil penerapan model pembelajaran Numbered Heads Think Talk Write Together terhadap kemampuan berpikir kreatif dan hasil belajar siswa.Perhitungan statistik yang digunakan sebagai berikut:

\section{Uji Normalitas}

Uji normalitas data dilakukan untuk mengetahui apakah data yang diperoleh berdistribusi normal atau tidak. Dalam penelitian ini, pengujian normalitas data menggunakan rumus KolmogorovSmirnov(Siregar, 2014:153) dengan prosedur sebagai berikut:

$\mathrm{H}_{0}=$ Data berasal dari populasi yang berdistribusi normal

$\mathrm{H}_{1}=$ Data berasal dari populasi yang tidak berdistribusi normal

Rumus:

$$
\begin{aligned}
& S=\sqrt{\frac{\sum(\mathrm{x}-\overline{\mathbf{x}})^{2}}{\mathrm{n}}} \\
& \mathbf{Z}_{\mathbf{X}}=\frac{\mathrm{x}-\overline{\mathrm{x}}}{\mathrm{S}}
\end{aligned}
$$

Taraf signifikansi 0,05

Kaidah keputusan:

$\mathrm{H}_{0}$ ditolak jika: $\mathrm{a}_{\text {maks }}>\mathrm{a}_{\text {tabel }}$ 
Terakreditasi Peringkat 4 (No. SK: 36/E/KPT/2019)

\section{$\mathrm{H}_{\mathrm{a}}$ diterima jika: $\mathrm{a}_{\text {maks }}>\mathrm{a}_{\text {tabel }}$ \\ Uji Homogenitas}

Uji homogenitas dilakukan untuk mengetahui apakah sampel yang diteliti homogen (seragam) atau tidak. Pengujian homogenitas pada penelitian ini dengan menggunakan distribusi F. Siregar (2014:169)menyatakan bahwaUji homogenitas varians dilakukan dengan menggunakan tahapan-tahapan sebagai berikut:

a. Menghitung rata-rata nilai kelompok sampel

$$
\overline{X_{\iota}}=\frac{\sum X_{i}}{n}
$$

Dimana:

$\bar{X} \quad=$ Nilai rata-rata sampel ke.. $i$

$\mathrm{X}_{\mathrm{i}} \quad=$ Data pada sampel ke.. $i$

$\mathrm{n} \quad=$ Jumlah data

b. Menghitung nilai varians kelompok sampel

$$
S_{i}^{2}=\sum \frac{\left(X_{i}-\overline{X_{l}}\right)^{2}}{n-1}
$$

c. Menentukan nilai $F_{\text {hitung }}$

$$
F_{\text {hitung }}=\frac{S_{B}^{2}}{S_{K}^{2}}
$$

Dimana:

$\mathrm{S}_{\mathrm{B}}{ }^{2} \quad=$ Varians yang lebih besar

$\mathrm{S}_{\mathrm{K}}{ }^{2} \quad=$ Varians yang lebih kecil

Data dikatakan memiliki varians homogen jika $F_{\text {hitung }}<F_{\text {tabel }}$, adapun sebaliknya jika $F_{\text {hitung }}>F_{\text {tabel }}$ varianstidak homogen.

\section{Uji-t/Uji Hipotesis}

Teknik statistik yang digunakan untuk menentukan taraf signifikansi perbandingan (membandingkan nilai rata-rata suatu kelompok dengan rata-rata kelompok yang lain) adalah uji-t atau $t$-test. Pasangan hipotesis nol dan tandingannya yang akan diuji adalah:

$$
\begin{aligned}
& \mathrm{H}_{0}=\bar{X}_{A}=\bar{X}_{B} \\
& \mathrm{H}_{1}=\bar{X}_{A} \neq \bar{X}_{B}
\end{aligned}
$$

Sartina(2014:46)

mengungkapkan

bahwauntuk mengetahui hipotesis penelitian data yang berdistribusi normal digunakan rumus uji-t atau $t$-testberikut:

$$
t=\frac{\bar{X}_{1}-\bar{X}_{2}}{\sqrt{\frac{s_{1}^{2}}{n_{1}}+\frac{s_{2}^{2}}{n_{2}}}}
$$

$\begin{array}{ll}\mathrm{t} & =\text { statistik } \mathrm{t} . \\ \overline{\mathrm{X}}_{1} & =\text { rata-rata hasil tes peserta didik }\end{array}$ pada kelas eksperimen

$\overline{\mathrm{X}}_{2} \quad=$ rata-rata hasil tes peserta didik pada kelas kontrol

$S_{1}^{2} \quad=$ varians kelas eksperimen

$S_{2}^{2} \quad=$ varians kelas kontrol

$\mathrm{n}_{1}=$ banyaknya peserta didik pada

kelas ekperimen

kelas kontrol

$\mathrm{n}_{2} \quad=$ banyaknya peserta didik pada

Kriteria pengujian yang berlaku adalah: $\mathrm{H}_{0}$ diterima jika $-t_{\left(1-\frac{1}{2} \propto\right)}<t<t_{\left(1-\frac{1}{2} \propto\right)}$.

\section{Uji IPK (Indeks Prestasi Kelompok)}

Uji IPK dalam penelitian ini digunakan untuk mengetahui apakah model pembelajaran Numbered Heads Think Talk Write Together cocok digunakan pada saat belajar berkelompok atau tidak, serta ingin mengetahui pengaruh pembelajaran berkelompok terhadap kemampuan berpikir kreatif siswa secara individu. Nurkancana \& Sumartana(1986:111) mengungkapkan bahwa untuk menghitung Indeks Prestasi Kelompok menggunakan rumus:

$$
I P K=\frac{\overline{\mathrm{x}}}{S M I} X 100 \%
$$

Dimana:

IPK = Indeks Prestasi Kelompok

$\overline{\mathrm{x}} \quad=$ Mean atau rata-rata

SMI = Skor Maksimal Ideal, skor yang dicapai jika semua soal dijawab benar.

Tabel 3.1 Kriteria indeks prestasi kelompok

\begin{tabular}{cc}
\hline Nilai & Keterangan \\
\hline $90 \%-100 \%$ & Sangat Tinggi \\
\hline $75 \%-89,99 \%$ & Tinggi \\
\hline $55 \%-74,99 \%$ & Sedang \\
\hline $30 \%-54,99 \%$ & Rendah \\
\hline $00-29,99 \%$ & Sangat Rendah \\
\hline
\end{tabular}

\section{HASIL PENELITIAN DAN \\ PEMBAHASAN \\ Hasil Penelitian}

Data yang diperoleh dalam penelitian ini adalah data kuantitatif berupa tes kemampuan 
berpikir kreatif siswa diperoleh dari hasil pretest dan posttest yang dilakukan di kelas eksperimen dan kelas kontrol. Tes kemampuan berpikir kreatif siswa sebanyak 10 butir soal uraian (essay) yang telah diuji validitasnya di kelas XI IPS SMA Negeri 1 Libureng Kec. Libureng sehingga instrumen ini layak digunakan dalam penelitian ini.

Hasil pretest kemampuan berpikir kreatif siswa

Data pretest yang diperoleh dari hasil tes kemampuan berpikir kreatif siswa pada kelas eksperimen dan kelas kontrol selanjutnya dianalisis dan dilakukan perhitungan. Hasil perhitungan pretest tersebut dapat dilihat pada tabel di bawah ini:

Tabel 4.1 Hasil pretest kelas eksperimen dan kelas kontrol

\begin{tabular}{ccc}
\hline Statistik & Kelas Eksperimen & Kelas Kontrol \\
\hline Jumlah Sampel & 25 & 25 \\
\hline Nilai Minimum & 16 & 22 \\
\hline Nilai Maksimum & 50 & 46 \\
\hline Mean & 32,08 & 32,72 \\
\hline Median & 30,75 & 32,55 \\
\hline Modus & 30,4 & 33,17 \\
\hline Varians & 54,70 & 27,85 \\
\hline Standar Deviasi & 7,55 & 5,39 \\
\hline
\end{tabular}

(Diadaptasi dari olah data)

Berdasarkan tabel di atas dapat diketahui bahwa dengan jumlah sampel kelas eksperimen dan kelas kontrol masing-masing sebanyak 25 siswa menghasilkan nilai rata-rata kelas ? lebih besar daripada kelas eksperimen, $\quad 67$ dapat dilihat dari perolehan nilai rata-rata kelas kontrol $(32,72)$ dengan varians $(27,85)$ lebih tinggi dari perolehan nilai rata-rata kelas eksperimen $(32,08)$ dengan varians $(54,70)$. Hasil pretest kedua kelas penelitian dapat dilihat pada lampiran C2 dan lampiran C3.

Kemudian data pretest kelas eksperimen dan kelas kontrol dihitung berdasarkan indikator masing-masing kemampuan berpikir kreatif siswa yang dapat dilihat pada tabel di bawah ini:
Tabel 4.2 Nilai rata-rata pretest indikator kemampuan berpikir kreatif

\begin{tabular}{cccccc}
\hline \multirow{2}{*}{ No. } & Indikator & $\begin{array}{c}\text { Kelas } \\
\text { Eksperimen }\end{array}$ & Kriteria & $\begin{array}{c}\text { Kelas } \\
\text { Kontrol }\end{array}$ & Kriteria \\
\hline 1 & $\begin{array}{c}\text { (Fluency) } \\
\text { Kelancaran }\end{array}$ & $41,87 \%$ & $\begin{array}{c}\text { Kurang } \\
\text { Kreatif }\end{array}$ & $39,20 \%$ & $\begin{array}{c}\text { Kurang } \\
\text { Kreatif }\end{array}$ \\
\hline 2 & $\begin{array}{c}\text { (Flexibility) } \\
\text { Keluwesan }\end{array}$ & $28,00 \%$ & $\begin{array}{c}\text { Kurang } \\
\text { Kreatif }\end{array}$ & $28,40 \%$ & $\begin{array}{c}\text { Kurang } \\
\text { Kreatif }\end{array}$ \\
\hline 3 & $\begin{array}{c}\text { (Elaboration) } \\
\text { Elaborasi }\end{array}$ & $29,07 \%$ & $\begin{array}{l}\text { Kurang } \\
\text { Kreatif }\end{array}$ & $29,87 \%$ & $\begin{array}{c}\text { Kurang } \\
\text { Kreatif }\end{array}$ \\
\hline 4 & $\begin{array}{c}\text { (Originality) } \\
\text { Keaslian }\end{array}$ & $26,00 \%$ & $\begin{array}{c}\text { Kurang } \\
\text { Kreatif }\end{array}$ & $31,60 \%$ & $\begin{array}{c}\text { Kurang } \\
\text { Kreatif }\end{array}$ \\
\hline
\end{tabular}

(Diadaptasi dari olah data)

Tabel indikator hasil kemampuan berpikir kreatif di atas menunjukkan bahwa nilai ratarata indikator kemampuan berpikir kreatif kelas eksperimen tertinggi sebesar 41,87\% dengan kriteria kurang kreatif pada indikator kelancaran (fluency) dan nilai rata-rata terendah sebesar 26,00\% dengan kriteria kurang kreatif pada indikator keaslian (originality). Sedangkan nilai rata-rata indikator kemampuan berpikir kreatif kelas kontrol tertinggi sebesar $39,20 \%$ dengan kriteria kurang kreatif pada indikator kelancaran (fluency) dan nilai ratarata terendah sebesar $28,40 \%$ dengan kriteria kurang kreatif pada indikator keluwesan (flexibility). Secara keseluruhan indikator hasil pretest kemampuan berpikir kreatif siswa kelas eksperimen dan kelas kontrol adalah sama, yaitu kurang kreatif.

\section{Hasil posttest kemampuan berpikir kreatif siswa}

Setelah menerapkan model pembelajaran Numbered Heads Think Talk Write Together pada kelas eksperimen dan menerapkan model pembelajaran konvensioanal pada kelas kontrol, selanjutnya dilakukan pengumpulan data posttest. Data posttestyang diperoleh dari hasil tes kemampuan berpikir kreatif pada kedua kelas tersebut kemudian dianalisis dan dilakukan perhitungan. Hasil perhitungan kedua kelas tersebut dapat dilihat pada tabel di bawah ini:

Tabel 4.3 Hasil posttest kelas eksperimen dan kelas kontrol

\begin{tabular}{ccc}
\hline Statistik & Kelas Eksperimen & Kelas Kontrol \\
\hline Jumlah Sampel & 25 & 25 \\
\hline Nilai Minimum & 52 & 28 \\
\hline Nilai Maksimum & 86 & 72 \\
\hline Mean & 72,56 & 54,88 \\
\hline Median & 74 & 54,85 \\
\hline
\end{tabular}


Jurnal Ilmiah Mandala Education

http://ejournal.mandalanursa.org/index.php/JIME/index

Terakreditasi Peringkat 4 (No. SK: 36/E/KPT/2019)

\begin{tabular}{ccc}
\hline Modus & 71,5 & 54,5 \\
\hline Varians & 58,43 & 77,65 \\
\hline Standar Deviasi & 7,80 & 8,99 \\
\hline
\end{tabular}

(Diadaptasi dari olah data)

Berdasarkan tabel di atas dapat diketahui bahwa dengan jumlah sampel kelas eksperimen dan kelas kontrol masing-masing sebanyak 25 siswa menghasilkan nilai rata-rata kelas eksperimen lebih besar daripada kelas kontrol, hal ini dapat dilihat dari perolehan nilai ratarata kelas eksperimen $(72,56)$ dengan varians $(58,43)$ lebih tinggi dari perolehan nilai ratarata kelas kontrol $(54,88)$ dengab varians $(77,65)$. Hasil posttest kedua kelas penelitian dapat dilihat pada lampiran $\mathbf{C 2}$ dan lampiran C3.

Berdasarkan data yang disajikan pada tabel di atas, selanjutnya data posttest kelas eksperimen dan kelas kontrol dihitung berdasarkan indikator masing-masing kemampuan berpikir kreatif siswa yang dapat dilihat pada tabel di bawah ini:

Tabel 4.4 Nilai rata-rata posttest indikator kemampuan berpikir kreatif

\begin{tabular}{cccccc}
\hline \multirow{2}{*}{ No } & Indikator & $\begin{array}{c}\text { Kelas } \\
\text { Eksperimen }\end{array}$ & Kriteria & $\begin{array}{c}\text { Kelas } \\
\text { Kontrol }\end{array}$ & Kriteria \\
\hline 1 & $\begin{array}{c}\text { (Fluency) } \\
\text { Kelancaran }\end{array}$ & $84,00 \%$ & $\begin{array}{c}\text { Sangat } \\
\text { Kreatif }\end{array}$ & $64,27 \%$ & Kreatif \\
\hline 2 & $\begin{array}{c}\text { (Flexibility) } \\
\text { Keluwesan }\end{array}$ & $67,60 \%$ & Kreatif & $53,20 \%$ & $\begin{array}{l}\text { Cukup } \\
\text { Kreatif }\end{array}$ \\
\hline 3 & $\begin{array}{c}\text { (Elaboration) } \\
\text { Elaborasi }\end{array}$ & $70,67 \%$ & Kreatif & $53,87 \%$ & $\begin{array}{l}\text { Cukup } \\
\text { Kreatif }\end{array}$ \\
\hline 4 & $\begin{array}{c}\text { (Originality) } \\
\text { Keaslian }\end{array}$ & $63,20 \%$ & Kreatif & $44,00 \%$ & $\begin{array}{c}\text { Cukup } \\
\text { Kreatif }\end{array}$ \\
\hline
\end{tabular}

(Diadaptasi dari olah data)

Tabel indikator hasil kemampuan berpikir kreatif di atas menunjukkan bahwa nilai ratarata indikator kemampuan berpikir kreatif kelas eksperimen tertinggi sebesar 84,00\% dengan kriteria sangat kreatif pada indikator kelancaran (fluency) dan nilai rata-rata terendah sebesar 63,20\% dengan kriteria kreatif pada indikator keaslian (originality). Sedangkan nilai rata-rata indikator kemampuan berpikir kreatif kelas kontrol tertinggi sebesar $64,27 \%$ dengan kriteria kreatif pada indikator kelancaran (fluency) dan nilai rata-rata terendah sebesar $44,00 \%$ dengan kriteria cukup kreatif pada indikator keaslian (originality). Secara keseluruhan indikator hasil posttest kemampuan berpikir kreatif siswa kelas eksperimen dan kelas kontrol menunjukkan hasil yang jauh berbeda, hal ini membuktikan bahwa penerapan model pembelajaran Numbered Heads Think Talk Write Together dalam proses pembelajaran berpengaruh positif terhadap kemampuan berpikir kreatif siswa.

\section{Pembahasan}

Berdasarkan perhitungan data pretest yang telah dilakukan, diperoleh hasilrata-rata kemampuan berpikir kreatif siswa kelas eksperimen dan kelas kontrol seperti yang disajikan pada gambar di bawah ini:

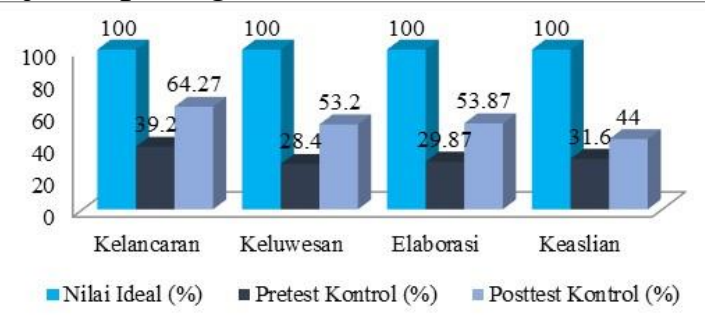

Gambar 4.3 Grafik hasil pretest dan posttest

kemampuan berpikir kreatif kelas kontrol

Berdasarkan gambar di atas dapat diketahui bahwa hasil pretest ke posttest pada kelas kontrol indikator kelancaran mengalami peningkatan sebesar $(25,07 \%)$, keluwesan $(24,8 \%)$, elaborasi $(24 \%)$ dan keaslian $(12,4 \%)$. Secara keseluruhan peningkatan kemampuan berpikir kreatif siswa kelas kontrol dengan menggunakan model pembelajaran konvensional sebesar $(21,57 \%)$.

Selanjutnya untuk mengetahui seberapa besar peningkatan kemampuan berpikir kreatif siswa dari pretest ke posttest pada kelas eksperimen dengan menerapkan model pembelajaran Numbered Heads Think Talk Write Togetherdapat dilihat pada gambar di bawah ini:

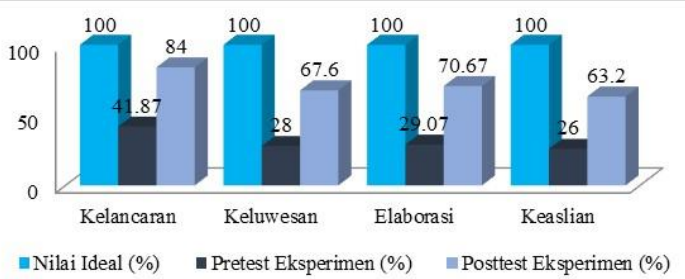

Gambar 4.4 Grafik hasil pretest dan posttest kemampuan berpikir kreatif kelas eksperimen

Berdasarkan gambar di atas dapat diketahui bahwa hasil pretest ke posttest pada kelas eksperimen indikator kelancaran 
mengalami peningkatan sebesar $(42,13 \%)$, keluwesan (39.6\%), elaborasi $(41,6 \%)$ dan keaslian (37,2\%). Secara keseluruhan peningkatan kemampuan berpikir kreatif siswa kelas eksperimen dengan menggunakan model pembelajaran Numbered Heads Think Talk Write Together sebesar $(40,13 \%)$.

Berdasarkan gambar 4.3 rata-rata peningkatan kemampuan berpikir kreatif siswa kelas kontrol dari pretest ke posttest melalui penerapan model pembelajaran konvensional sebesar $(21,57 \%)$. Sedangkan pada gambar 4.4 rata-rata peningkatan kemampuan berpikir kreatif siswa kelas eksperimen dari pretest ke posttest melalui penerapan model pembelajaran Numbered Heads Think Talk Write Together sebesar $(40,13 \%)$. Hal ini membuktikan bahwa penerapan model pembelajaran Numbered Heads Think Talk Write Together lebih baik dan berpengaruh positif terhadap kemampuan berpikir kreatif siswa dibandingkan dengan model pembelajaran konvensional.

\section{KESIMPULAN}

Nilai rata-rata posttest kelas eksperimen sebesar $(72,56)$ dan nilai rata-rata posttest kelas kontrol sebesar $(54,88)$ dengan derajat kebebasan $(\mathrm{dk})=\mathrm{n}_{1}+\mathrm{n}_{2}-2=25+25-$ $2=48$. Taraf signifikansi $\alpha=0,05$ dengan jumlah sampel (n) $=25$. Berdasarkan perhitungan uji hipotesis yang telah dilakukan, diperoleh nilai $t_{\text {hitung }}(7,59)>t_{\text {tabel }}(2,01063)$, maka $\mathrm{H}_{0}$ ditolak dan $\mathrm{H}_{\mathrm{a}}$ diterima sehingga dapat simpulkan bahwa terdapat perbedaan hasil posttest antara siswa kelas eksperimen dengan siswa kelas kontrol. Hal ini berarti bahwa ada pengaruh penerapan model pembelajaran Numbered Heads Think Talk Write Together terhadap kemampuan berpikir kreatif pada mata pelajaran ekonomi kelas XI IPS SMA Negeri 1 Patimpeng Kabupaten Bone.Pengujian IPK diperoleh nilai sebesar $(72,56)$ pada kelas eksperimen. Hal ini berarti kelas eksperimen setelah diberi perlakuan model pembelajaran Numbered Heads Think Talk Write Together mengalami perkembangan dari nilai IPK dengan kriteria rendah $(32,08)$ pada saat pretest kemudian berada pada nilai
IPK kriteria sedang $(72,56)$ pada saat posttest, sehingga dapat disimpulkan bahwa model pembelajaran Numbered Heads Think Talk Write Together cocok digunakan pada pembelajaran berkelompok karena melewati standar nilai KKM sebesar 70,00 yang ditetapkan sekolah pada mata pelajaran ekonomi.Melalui pembelajaran Numbered Heads Think Talk Write Together dengan jumlah siswa kelas eksperimen sebanyak 25, siswa yang mencapai standar nilai KKM sebanyak 17 atau $68 \%$.

\section{SARAN}

Hasil penelitian menunujukkan bahwa penerapan model pembelajaran Numbered Heads Think Talk Write Together dapat melatih dan meningkatkan kemampuan berpikir kreatif siswa. Oleh karena itu, diharapkan kepada guru agar menerapkan model pembelajaran tersebut di sekolah sebagai upaya untuk melatih dan meningkatkan kemampuan berpikir kreatif siswa. Penerapan model pembelajaran Numbered Heads Think Talk Write Together cenderung memerlukan waktu yang agak lama, maka diharapkan guru melakukan sedikit inovasi dalam pembelajaran agar siswa tidak mudah bosan dan jenuh.Hasil perhitungan Indeks Prestasi Kelompok (IPK) menunjukkan nilai dari kriteria rendah pada saat pretest, kemudian memeroleh nilai dengan kriteria sedang pada saat posttest, maka diharapkan guru melakukan sedikit perbaikan.

\section{DAFTAR PUSTAKA}

Abdi, J., Ikhsan, M \& Marwan. 2013. Meningkatkan Kemampuan Siswa Sekolah Menengah Atas dalam Menyelesaikan Soal Matematika Setara PISA melalui Pendekatan Konstruktivisme. Jurnal Peluang. Vol 1. No 2. Hal 51-62.

Afiah, L., Solehatin, E \& Raharjo. 2013. Upaya Peningkatan Aktivitas Belajar Siswa melalui Penerapan Pembelajaran Kooperatif Tipe Jigsaw pada Mata Pelajaran PKn di SMP Negeri 1 Cikarang Barat. Jurnal PPKn UNJ Online. Vol 1. No 2. Hal 1-10. 
Alpusari, M. 2014. Analisis Butir Soal Konsep Dasar IPA 1 melalui Penggunaan SProgram Komputer Anates Versi 4.0 for Windows.Jurnal Primary, Vol 3. No 2. Hal 106-115.

Andarini, T., Masykuri, M \& Sudarisman, S. 2012. Pembelajaran Biologi Menggunakan Pendekatan CTL (Contextual Teaching Learning) melalui Media Flipchart dan Video ditinjau dari Kemampuan Verbal dan Gaya Belajar. Jurnal Inkuiri, Vol 1. No 2. Hal 93-104.

Arikunto, S. 2006. Prosedur Penelitian Suatu Pendekatan Praktik. Jakarta: Rineka Cipta.

Astriani, D E \& Sucihatiningsih, D W P. 2014. Efektivitas Penerapan Metode Pembelajaran Kooperatif tipe TGT (Team Game Tournament) untuk Meningkatkan Hasil Belajar Kompetensi Dasar Kegiatan Pokok Ekonomi Siswa Kelas VII SMP N 1 Jati Kudus. Economic Education Analysis Journal, Vol3. No 1. Hal 5258.

Astutik, S., Cahyani, A D \& Sophan, M K. 2014. Sistem Penilaian Esai Otomatis pada E-Learning dengan Algoritma Winnowing. Jurnal Informatika, Vol 12. No 2. Hal 47-52.

Atikasari, G \& Kurniasih, A W. 2015. Keefektifan Model Pembelajaran Koopertif dengan Strategi TTW Berbantuan Geogebra terhadap Kemampuan Berpikir Kreatif Matematis Siswa Kelas VII Materi Segitiga. Unnes Journal of Mathematics Education, Vol 4. No 1. Hal 85-94.

Ayuningtyas, Y. 2011. Hubungan Media Puzzle dangan Hasil Belajar Mata Pelajaran Ekonomi di SMA Negeri 1 Citeureup.Skripsi. Jakarta: Fakultas Ilmu Tarbiyah dan Keguruan Universitas Islam Negeri Syarif Hidayatullah Jakarta.
Darmawanti, R. 2010. Efektivitas Pembelajaran Ekonomi pada Materi Pajak dengan Model Pembelajaran Teams Games Tournament (TGT).Skripsi. Jakarta: Fakultas Ilmu Tarbiyah dan Keguruan Universitas Islam Negeri Syarif Hidayatullah Jakarta.

Ellan., Hobri \& Nurcholif. 2013. Pengembangan Perangkat Pembelajaran Matematika Bernuansa Karakter dengan Pembelajaran Kooperatif Numbered Head Together (NHT) Pokok Bahasan Operasi Bentuk Aljabar Kelas VII SMP Negeri 1 Pakusari Tahun Ajaran 2012/2013. Pancaran, Vol 2. No 1. Hal 1-12.

Febriany, D D. 2013. Pengaruh Pembelajaran Kooperatif Tipe Numbered Heads Together (NHT) untuk Meningkatkan Hasil Belajar Akuntansi. Jupe UNS, Vol 1, No 2, Hal 1 s/d 11.

Gunarto. 2010. Penerapan Assesment Autentic dalam Pembelajaran Bahasa Indonesia di SMP Negeri 2 Delanggu Kabupaten Klaten. Magistra, No 73. Th XXII. Hal 6-17.

Haji, S. 2014. Strategi Think-Talk-Write (TTW) untuk Meningkatkan Kemampuan Representasi Matematik.Prosiding Seminar Nasional Matematika Program Pascasarjana STKIP Siliwangi Bandung. Vol 1. Hal 49-56.

Hamdani, D dkk. 2012. Pengaruh Model Pembelajaran Generatif dengan Menggunakan Alat Peraga terhadap Pemahaman Konsep Cahaya KelasVIII di SMP Negeri 7 Kota Bengkulu. Jurnal Exacta, Vol X. No 1. Hal 79-88.

Haryono, A. 2012. Pengembangan Modelmodel Pembelajaran Berbasis Economic Literacy Siswa SMA. Jurnal Penelitian Kependidikan, Vol 22. No 1. Hal 1-11.

Herawati, D D., Wahyuni, D \& Prihatin, J. 2014. Penerapan Model Pembelajaran Kooperatif Tipe NHT (Numbered 
Terakreditasi Peringkat 4 (No. SK: 36/E/KPT/2019)

Head Together) dengan Media Komik pada Materi Pengelolaan Lingkungan guna Meningkatkan Motivasi dan Hasil Belajar (Siswa Kelas VII C SMP Negeri 1 Semboro Jember). Pancaran, Vol 3. No 3. Hal 73-82.

Hidayat, S., Festiyed \& Fauzi, A. 2012. Pengaruh Pemberian Assessment Essay terhadap Pencapaian Kompetensi Siswa dalam Pembelajaran Fisika Menggunakan Pendekatan Ekspositori dan Inkuiri di Kelas XI IA SMA N 1 Kecamatan Suliki Kabupaten Lima Puluh Kota.Jurnal Penelitian Pembelajaran Fisika 1, Hal 1-14.

Indrawati. 2011. Perencanaan Pembelajaran Fisika: Model-model Pembelajaran Implementasinya dalam Pembelajaran Fisika. Jember: Kementerian 